\title{
The significance of friendship in UK single mothers' intimate lives
}

\section{Dr Charlotte Morris}

\section{Abstract}

This article explores friendship as an aspect of the intimate lives of heterosexual single mothers. It has been argued that friendship holds an increasing significance in intimate lives, against a backdrop of increasing choice and declining emphasis on kinship ties. In this context, friendship has been viewed as displacing the centrality of heteronormative romantic relationships and, in this research, friendships were often accorded a higher status. In this narrative study, participants related shifts in their personal landscapes of intimacy on becoming single mothers. Friendships were narrated as multifaceted, offering practical and emotional support, alongside acceptance. Foregrounding friendship provided possibilities for positive identifications in a context in which single mothers are often subject to judgements. While friendships were not usually described as an alternative to couple-centred family life - which retained its status as the ideal intimate form - for some, single motherhood entailed an opening out of intimate possibilities beyond the couple.

\section{Introduction}

This article explores the significance of friendship in the intimate lives of single mothers. The topic of friendship has gained increasing prominence (Allan, 2011) alongside the broader sociology of intimacy and personal life (Smart, 2007; Gabb, 2010). Friendship is viewed as a reciprocal intimate bond that is entered into and sustained voluntarily. For Spencer and Pahl (2004), it is relational and achieved; the label of 'friend' is indicative of the quality of a relationship. Friendship can hold different degrees of emotional intensity and trust with variance across times and cultures (Allan, 
1989), and within the current Western context may take precedence over romantic and family ties (Jamieson et al, 2006). Pahl and Spencer (2003) ask whether the significance attached to friendship is specific to contemporary life, and question the dichotomy of 'ascribed traditional family ties' and 'chosen friendship ties' of the present.

This article argues that the intimate lives of single mothers contain possibilities for intimacy and identities beyond the heteronormative couple-based family, and that friendship is key to this. It builds on arguments that friendship is accorded a heightened significance as an aspect of decentring heteronormative intimate forms (Weston, 1997; Weeks et al, 2001; Roseneil and Budgeon, 2004). Friendships take on further significance and intensity at times of transition (Rebughini, 2011), particularly where people are located on the boundaries of heteronormativity (Weeks et al, 2001). The foregrounding of friendship within intimacy narratives has been found to be an important aspect of 'identity work' for single people whose identities are positioned as outside normative ideals of couple-based intimacy (Budgeon, 2008). This is likely to be exacerbated for women (Simpson, 2016) and women with children in particular - positioned as 'lacking' without a father figure (Butler, 2000).

This study (Morris, 2014) captured narratives of intimate lives and the shifting personal landscapes of intimacy that becoming a single mother often entailed (Layne, 2015; Morris, 2015). A 'landscape of intimacy' is understood as a shifting, dynamic web of connections of people considered to be important in someone's life, through emotional closeness, mutual disclosure (Jamieson, 1998), proximity and/or provision of practical support and care. This reflects Spencer and Pahl's (2004) concept of 'personal communities', defined as individuals' microsocial worlds of significant others. The term 'landscapes of intimacy' further denotes wider social shifts that intertwine with individual intimate lives (Jamieson et al, 2006), making certain intimacies more or less possible. It allows for ways in which the scope and quality of relationships shift, through changing biographies and circumstances. 


\section{Friendship and intimacy}

Individualisation theories posit that we live in an era marked by transformation of intimacy (Giddens, 1992; Beck and Beck-Gernsheim, 1995) involving increasing choice, autonomy and egalitarianism, thus opening the way for more democratic relating. This, it is argued, is an aspect of detraditionalisation and a movement away from 'traditional' family; Beck and Beck-Gernsheim (1995) discussed 'pioneers of change' experimenting with new intimate forms. Other theorists have highlighted increasingly transient intimacies associated with moral decline and consumerism (Bauman, 2003). Critics have drawn attention to overstatements of change (Duncan, 2011); a disregard for continuing socioeconomic and gendered inequalities and lack of empirical evidence (Jamieson, 1998); an implicit assumption of the (hetero)couple (Simpson, 2016); and an obfuscation of class (Skeggs, 2004; Gillies, 2007) and overreliance on notions of rational, atomised, disembedded lives (Smart, 2007; May, 2013), devoid of care and interdependencies (Fineman, 2004).

Nevertheless, such theories have provided a touchstone for intimacy studies (Gabb, 2010). Roseneil and Budgeon's (2004) work highlights an increasing fluidity and 'queering' of relationships through disruption of heteronormative practices. Building on notions of 'families of choice' (Weston, 1997), it is argued that the heterosexual love relationship has become increasingly decentred within individual life narratives, and that there is more experimentation beyond 'heteronormative conjugality' with an increasing importance placed on friendship. Roseneil (2005) contends that the boundaried concept of 'family' is less useful than networks and flows of intimacy and care. Weeks et al (2001) argue that for those operating on the boundaries of heteronormativity, friendships can take on especial significance, meaning and intensity. While primarily discussing the lives of nonheterosexual individuals, this is pertinent to single mothers who are frequently positioned at the outer edges of heteronormativity (Butler, 2000).

However, these arguments are subject to the critiques of individualisation in that it is important not to overstate change (Duncan, 2011). Indeed, Plummer (2003) suggested that a contemporary 
challenge is to navigate co-existing traditional, modern and postmodern modes of intimacy. Duncan (2011) rejects the assertion that contemporary personal lives are radically different from those of the past. While it is possible to trace certain 'improvements' in contemporary life, including an increasing acceptance of homosexuality, such changes are 'improvised developments' rather than radical transformations: People act pragmatically, adapting to circumstances, with some taking up more 'traditional' or 'progressive' positions than others. As Evans (1993) observed, British cultural life contains contradictory strands of liberalism and conservatism, diversity and tradition, change and continuities to be negotiated; paradoxically, an increasing plurality of intimate forms co-exist with highly popularised, fixed notions of 'traditional' family and 'normality'. Such contradictions continue and indeed, Simpson (2016) notes, a continued 'prioritizing of coupledom through policy and legislation' produces discriminatory effects (Simpson, 2016: 387) ${ }^{1}$. Gabb (2010) highlights the continuing importance attributed to 'the couple' relationship as an ideal to be aspired to. Yet friendship has a discursive power; invoked to describe enduring ties, the rhetoric of friendship is applied to partners to emphasise the strength of a bond.

Evans (2003) observes the enduring cultural centrality of idealised romantic love. Kaufman (2008) argues that there is still an attraction to traditional models of intimacy, with romantic notions of meeting 'the one' dominating women's fantasy lives, incorporating cultural variations of a fairy tale prince figure, who they are fated to meet (Kaufman, 2008: 47). While living alone is part of a historical trend (see Jamieson and Simpson, 2013), there is a concurrent re-centring of the family due to global economic and political uncertainty and shifting welfare regimes. This context, it is argued, has precipitated a resurgence of pity for single women who in previous eras may have been portrayed as liberated and competent. Single women are instead positioned as emotionally abnormal and undesirable, their status continually called into question. Women may therefore long for acceptance and stability against a backdrop of complexity; marriage, the family and loving couple ideals offering foundations and boundaries to stabilise identities (although these concepts are recognised as historically relative, complex and precarious) (Kaufman, 2008). 
Budgeon (2008), conversely, in a study on singleness, found that research participants were able to re-construct singleness as a positive identity, although at variance with normativity; employing a 'distancing' strategy, they questioned ideal coupledom and romantic love. Inhabiting an 'outsider' status in relation to heteronormativity 'resulted in a subject position from which individuals could critically reflect on their own experiences' (Budgeon, 2008: 312). Participants highlighted advantages to being single, although many did not rule out (re)partnering in the future. Ultimately, the experience of being single and the subsequent questioning this entailed opened up the possibility of managing intimate lives outside heteronormativity - for example, refusing cohabitation, choosing emotional but not sexual fidelity, and focusing on ties with friends rather than romantic and sexual relationships. Simpson (2016) reported similar findings in an analysis of the narratives of nevermarried single women spanning several generations, but contended that single women may have long been engaged in apparently 'novel' modes of intimacy. Despite the possibility of constructing positive identities, single women are still depicted as threatening to society in their apparent refusal of gendered heteronorms (Simpson, 2006). This observation may be especially applicable to single mothers, assumed to be desperate for the support of a man, promiscuous or refusing to live in accordance with 'family values' (Gillies, 2007; Tyler 2008).

\section{Methodology}

A narrative approach enabled me to capture complexity in single mothers' intimate lives and the way in which they see themselves as intimate beings within their specific contexts. In order to study the interweaving of everyday intimacies with the realm of wider cultural narratives, and individual biographies with wider social changes, Smart recommends the narrative approach adopted here (2007), observing its potential to capture the fluidity and complexity of shifting lives, histories and webs of relationships, and to explore their meanings for individuals. This approach enables researchers to capture multifaceted aspects of lives, recognising that they are not 
compartmentalised (Goodson and Sikes, 2001), allowing exploration of the interweaving of individual lives with socio-historical contexts (Plummer, 1995), demonstrating ways in which participants construct identities (Plummer, 1995) and make sense of lives in transition, especially when affected by disruption (Riessman, 1993; Becker, 1997). Smart and Neale (1999) observed that divorced women often embark on processes of remaking selves, ideally captured through narrative. Narrative interviews provided insights into ways in which intimate practices shift through choices, circumstances, normalised expectations or resistances. As opposed to focusing on specific aspects of lives, this approach drew out ways in which participants themselves conceptualised, made sense of and shaped the intimate realm of their existence as single women with children.

My doctoral research was undertaken at the University of Sussex (Morris, 2014)² and ethical approval was granted by the university's ethics committee. Twenty-four interviews were conducted with heterosexual single mothers aged between 30 and 55, living in a variety of locations in the South East of England. This generational cohort coincided with a period identified as a time of transformation in terms of intimacy (Giddens, 1992). It also reflected the average age of single mothers (38)3. Acknowledging complexities and fluid, shifting situations (May, 2004), the study recruited participants who self-identified as single mothers. While the word 'lone' is often used, it is not a term typically used in everyday life, and connotes that parenting is solely down to one individual - those defined as 'lone' parents may well be supported by families, friends and local communities and the household may be shared by others. The study explicitly set out to explore the experiences of heterosexual women, with heterosexuality usually assumed and unproblematised (van Every, 1996; Jackson, 2005; Hockey et al, 2007). However, it is acknowledged that as a category, heterosexuality is not clear-cut and contains diverse experiences. Further features of the sample are summarised here:

\section{Table 1: Summary of participants}




\begin{tabular}{|c|c|c|c|c|c|}
\hline Participant & $\begin{array}{l}\text { Route to } \\
\text { single } \\
\text { motherhood }\end{array}$ & $\begin{array}{l}\text { Age (or } \\
\text { approximate) }\end{array}$ & $\begin{array}{l}\text { Number and } \\
\text { approximate } \\
\text { age of } \\
\text { children }\end{array}$ & Occupation & \begin{tabular}{|l} 
Social \\
background
\end{tabular} \\
\hline 1 & $\begin{array}{l}\text { Escape from } \\
\text { domestic } \\
\text { abuse }\end{array}$ & 45 & $\begin{array}{l}2 \text { (teenager / } \\
\text { under 25) }\end{array}$ & $\begin{array}{l}\text { Full-time } \\
\text { professional }\end{array}$ & Working-class \\
\hline 2 & $\begin{array}{l}\text { Abandoned } \\
\text { during } \\
\text { pregnancy }\end{array}$ & 43 & $1(9)$ & $\begin{array}{l}\text { Unemployed, re- } \\
\text { training }\end{array}$ & Middle-class \\
\hline 3 & $\begin{array}{l}\text { Relationship } \\
\text { breakdown }\end{array}$ & 50 & $\begin{array}{l}3 \text { ( } 2 \text { under } \\
10,1 \\
\text { teenager) }\end{array}$ & $\begin{array}{l}\text { Unemployed, } \\
\text { part-time } \\
\text { volunteer }\end{array}$ & Working-class \\
\hline 4 & $\begin{array}{l}\text { Escape from } \\
\text { domestic } \\
\text { abuse }\end{array}$ & Late forties & $\begin{array}{l}2 \text { (under } 10), \\
2 \text { estranged }\end{array}$ & Unemployed & Working-class \\
\hline 5 & $\begin{array}{l}\text { Relationship } \\
\text { breakdown }\end{array}$ & 55 & 1 (under 16) & $\begin{array}{l}\text { Full-time } \\
\text { employed }\end{array}$ & Working-class \\
\hline 6 & $\begin{array}{l}\text { Domestic } \\
\text { violence, } \\
\text { separation } \\
\text { and } \\
\text { bereavement }\end{array}$ & Mid-forties & 2 (under 10) & $\begin{array}{l}\text { Unemployed, } \\
\text { part-time } \\
\text { volunteer }\end{array}$ & Working-class \\
\hline 7 & $\begin{array}{l}\text { Escape from } \\
\text { domestic } \\
\text { abuse }\end{array}$ & 34 & 3 (under 10) & Unemployed & $N / A$ \\
\hline 8 & $\begin{array}{l}\text { Relationship } \\
\text { breakdown }\end{array}$ & Late forties & $\begin{array}{l}5 \text { (between } 9 \\
\text { and } 30 \text { ) }\end{array}$ & Unemployed & Working-class \\
\hline 9 & $\begin{array}{l}\text { Relationships } \\
\text { breakdown }\end{array}$ & Early forties & $\begin{array}{l}2 \text { (1 under } \\
16,1 \text { under } \\
20)\end{array}$ & $\begin{array}{l}\text { Part-time } \\
\text { professional }\end{array}$ & $N / A$ \\
\hline 10 & $\begin{array}{l}\text { Relationship } \\
\text { breakdown }\end{array}$ & 31 & 1 (under 10) & $\begin{array}{l}\text { Unemployed, in } \\
\text { part-time study }\end{array}$ & $N / A$ \\
\hline 11 & $\begin{array}{l}\text { Relationship } \\
\text { breakdown }\end{array}$ & 33 & 1 (under 10) & $\begin{array}{l}\text { Full-time } \\
\text { employed }\end{array}$ & $N / A$ \\
\hline 12 & $\begin{array}{l}\text { Relationship } \\
\text { breakdown }\end{array}$ & 50 & $\begin{array}{l}3 \text { (between } \\
10 \text { and } 22 \text { ) }\end{array}$ & $\begin{array}{l}\text { Full-time } \\
\text { professional }\end{array}$ & Working-class \\
\hline 13 & Separation & 33 & 2 (under 16) & $\begin{array}{l}\text { Full-time } \\
\text { professional }\end{array}$ & Middle-class \\
\hline 14 & $\begin{array}{l}\text { Relationship } \\
\text { breakdown }\end{array}$ & 37 & 1 (under 10) & $\begin{array}{l}\text { Full-time } \\
\text { employed }\end{array}$ & $N / A$ \\
\hline 15 & $\begin{array}{l}\text { Abandonment } \\
\text { during } \\
\text { pregnancy }\end{array}$ & Early forties & 1 (under 16) & $\begin{array}{l}\text { Full-time } \\
\text { professional }\end{array}$ & Middle-class \\
\hline 16 & Separation & 49 & 1 (under 16) & $\begin{array}{l}\text { Full-time } \\
\text { employed }\end{array}$ & $N / A$ \\
\hline 17 & $\begin{array}{l}\text { Unplanned } \\
\text { pregnancy }\end{array}$ & 49 & 1 (under 10) & Unemployed & Middle-class \\
\hline 18 & $\begin{array}{l}\text { Relationship } \\
\text { breakdown }\end{array}$ & 42 & 2 (under 10) & $\begin{array}{l}\text { Full-time } \\
\text { employed }\end{array}$ & Middle-class \\
\hline
\end{tabular}




\begin{tabular}{|c|c|c|c|c|c|}
\hline 19 & $\begin{array}{l}\text { Relationship } \\
\text { breakdown }\end{array}$ & 39 & 2 (under 12) & $\begin{array}{l}\text { Full-time } \\
\text { professional }\end{array}$ & N/A \\
\hline 20 & $\begin{array}{l}\text { Relationship } \\
\text { breakdown }\end{array}$ & 42 & 1 (under 16) & $\begin{array}{l}\text { Part-time } \\
\text { professional }\end{array}$ & Middle-class \\
\hline 21 & $\begin{array}{l}\text { Relationship } \\
\text { breakdown }\end{array}$ & 33 & 1 (under 10) & $\begin{array}{l}\text { Part-time } \\
\text { professional }\end{array}$ & $\mathrm{N} / \mathrm{A}$ \\
\hline 22 & Abandonment & 39 & 2 (under 6 ) & Unemployed & N/A \\
\hline 23 & $\begin{array}{l}\text { Relationship } \\
\text { breakdown, } \\
\text { illness }\end{array}$ & Mid-forties & 2 (under 12) & Unemployed & Middle-class \\
\hline 24 & $\begin{array}{l}\text { Relationship } \\
\text { breakdown }\end{array}$ & 55 & 2 (under 25) & $\begin{array}{l}\text { Full-time } \\
\text { employed }\end{array}$ & N/A \\
\hline
\end{tabular}

A variety of recruitment strategies were deployed: an invitation was posted via a local lone parent network; the research project was introduced to single-parent volunteers and participants on a course for unemployed lone mothers; flyers were distributed; and a snowballing technique was employed. The most successful techniques were those when participants were approached face to face, possibly due to the sensitive nature of the topic area. The interviews entailed four main sections: an introductory section; narrative elicitation; follow-up questions; and a semi-structured section. They began with introducing the study, discussing participant information and consent and answering generic questions to put participants at ease. I prompted participants to tell their story, utilising open 'tell me...' questions. The narrative section was unstructured, allowing participants to tell their stories with no interruption unless to clarify a point, or occasionally to encourage interviewees to expand on an interesting train of thought. I asked further probing questions and then offered tentative interpretations to seek participants' responses. Semi-structured questions elicited further material to address specific research questions. All interviews were recorded and transcribed in full, and pseudonyms were used.

A multilayered strategy (Riessman, 1993) was adopted for data analysis - structural, thematic and discursive - to enable in-depth understanding of participants' intimate lives and the ways in which they made sense of their experiences. Lieblich et al's (1998) model for the classification of narrative readings was drawn on in this process. The first stage (defined as holistic-form) involved looking at 
the overall structure of narratives, observing common features and genres. Holistic-content analysis identified broad common themes within and across the narratives. A final stage (categorical form analysis) entailed attending to the discursive resources participants drew on. This was guided by a feminist critical lens, identifying gendered narratives and discourses surrounding intimacy.

\section{Summary of narratives}

Three broad narrative genres were identified; lives being spoiled, survival and transformation. Participants frequently began their narratives by relating experiences of relationship breakdown and the material and emotional challenges of adjusting to parenting alone. Six participants narrated their lives as irreparably spoiled, expressing disappointment that relationships had failed to live up to expectations (Hockey et al, 2010), whether in terms of romance, stability or equality (Morris, 2015). Relationship breakdown further entailed the loss of heteronormative 'married mother' statuses. Emphasising that single motherhood was not of their choosing and expressing a sense of anger and injustice enabled participants to dis-identify with this stigmatised identity. In several cases participants idealised traditional couple-centred families, in some cases decrying the lack of a father figure. Concerns were raised about 'moral decline', drawing on popular discourses and notions that men currently lack commitment and responsibility (in alignment with contemporaneous discourses around 'feckless fathers'). Participants thereby adopted the position of the 'outsider' commentating on society, enabling further distancing from non-normative identities (Budgeon, 2008). These participants at the time of interview may have felt unable to revise narratives, make sense of disruption and re-imagine their futures. A combination of isolation and lack of resources may have contributed to this (Squire, 2008) and, as will be discussed in the section on 'barriers', friendship was often missing for these participants.

The majority of the participants drew on narratives of 'survival' (Plummer, 1995), emphasising how they coped with everyday challenges (Klett-Davis, 2007) ${ }^{5}$. Some also highlighted the importance of 
'self-development', identified as crucial for women coming to terms with divorce (Smart and Neale, 1999). Simultaneously, there were identifiable therapeutic narrative discourses of 'recovery' (Plummer, 1995). The ability to 'cope', adapt and stay strong for children can be viewed as an aspect of 'identity work', enabling participants to draw on positive gendered identifications with good mothering (Skeggs, 1997). Affirming the value of friendships enabled participants to formulate positive identities and emphasised an ability to adapt to lives without a partner (Budgeon, 2008).

'Transformation' indicates moving into a new phase or identity, reflecting a redemptive narrative movement in contrast to narratives of lives being spoiled (McAdams and Bowman, 2001). A minority (approximately five) of narratives were transformative, and in several cases this reflected their circumstances; for example, children might have grown older, leaving more space and time for friendships and other pursuits. 'Transformation narratives' tended to convey possibilities for exploring new intimacies and rediscovering a sense of personhood - often privileged at least temporarily above the formation of new romantic relationships. Friendship was often presented as key to this. It is important to emphasise that there was much diversity and complexity within these broader narratives, and participants drew on a wide range of discursive resources throughout (Duncan, 2011).

\section{Friendship and transition to single motherhood}

Transitions to single motherhood often entailed disruption to lives and personal landscapes of intimacy. When asked who they felt closest to, participants usually answered 'children' followed by 'friends', while some participants immediately stated that it was 'friends'. Friends typically became increasingly central to participants' lives, whereas family members tended to be narrated as more peripheral. As Budgeon (2008) observes, this foregrounding of friendships can be one way of reworking identities operating outside heteronormative ideals of romantic coupledom. While there was a general perception that single mothers are not as stigmatised as they once were, participants 
were highly aware of negative depictions of single motherhood, and had lived through perceptions of a decline in 'family values', usually connected to working class mothers (Gillies, 2007), and some had experienced negative responses from others. Close friendships were presented as offering emotional connection, acceptance and reciprocal, practical support. They were usually formed through local communities and schools, with women in similar circumstances ${ }^{6}$, often with children of similar ages to their own, enabling some sharing of childcare and other forms of support. This is more suggestive of reciprocity and localised embededdness of intimacies (Smart, 2007; May, 2013) than the constructions of disembedded, autonomous individuals that characterise individualisation theories.

Some participants related distance from families; there were cases where family members were disapproving of their situations, disappointed with the failure of relationships and judgemental about their new lives. In many cases, their children's fathers' family became more distanced (in some instances, hostile) (also identified in Klett-Davies, 1997). As Spencer and Pahl (2006) observe, friendships take on a new significance where family relationships have deteriorated, while for Roseneil and Budgeon (2004), friendship has increased in significance more broadly. In some cases, the geographical upheaval of separation, alongside lack of understanding from family members, meant that families were positioned as secondary in terms of meeting intimate and practical needs. Becoming a single mother frequently entailed difficult material circumstances, necessitating a focus on immediate welfare needs. Housing and employment was often insecure, and there were high levels of anxiety about the impact of these circumstances on children. Safety was of particular concern in relation to potential new partners, particularly for those who had experienced abuse. It is understandable why single mothers would seek intimacy with women in similar situations to help them navigate complexities and insecurities, providing 'indispensable frameworks for negotiating the hazards of everyday life' (Weeks et al, 2001: 21). 
Participants reported that the development of meaningful and lasting female friendships, especially with other single mothers, was a positive aspect of single motherhood. Friendship could take on a heightened status, portrayed as a pinnacle of intimate connection as opposed to poor relationships (Roseneil, 2004), which seldom lived up to idealised versions of heterosexual intimacy (Hockey et al, 2010). With lives in flux, participants turned to friends for acceptance and a sense of belonging (May, 2013), reflecting Rubighini's (2011) emphasis on the importance of friends at times of transition and Budgeon's (2008) observation that foregrounding friendships was one way of formulating positive single identities. Some participants conveyed a decline in social status linked to negative stereotypes of single mothers, and engaging in identity work is therefore likely to have been important. Invoking friendship as representing positive aspects of single motherhood facilitated this alongside emphasising the shared normative status of motherhood as a counterpoint to negative depictions.

\section{Emotional connection}

Helen (50), a mother of three, described how she had initially sought emotional closeness in romantic relationships. However, her social circle had broadened and she enjoyed an increasing emotional closeness with friends. Her narrative was transformative, capturing a shift from a reliance on one person towards a friendship group that satisfied many intimacy needs. While friends may not fulfil sexual needs, Helen described relationships involving disclosure and sharing at levels that she perceived may not be possible with men due to differences and communication barriers between genders and more emotionally articulate responses from women. She stated that her expectations of men had been altered, and she no longer sought in-depth emotional connection with boyfriends. Mutual understanding, relaxation and fun were further aspects of friendships that she enjoyed. Indeed, Spencer and Pahl (2006) identified a distinct category of 'fun friends'; here it indicates a welcome release from the responsibilities of single parenthood. By prioritising friendship and 
identifying its benefits, Helen resisted couple-centred ideals of intimate life, presenting a positive single-mother identity:

'Certainly as I've got older or maybe because I've been on my own more, I wouldn't look for everything in one person. I've got a good group of girlie friends - some single, some married and I've realised now that.... I don't think I would want to put all my eggs in one basket with one person again.... I have fun and different sorts of giggles and laughs with my girlie-friends and I'm not sure my partner would be in that role.'

Helen described difficulties communicating with her husband, challenging suggestions of increasing negotiation and 'opening out' between men and women (Beck and Beck-Gernsheim, 1995). It is pertinent to note the differentiation between predominantly physical relationships with men and emotional connections with female friends. For Elizabeth (49), a mother of one, the sexual nature of relationships with men represented a barrier to disclosure, again contrasting with theories of individualisation. She stated that she was closest to her female friends, one advantage being that friendship is uncomplicated by sex. It was depicted as a non-judgemental relationship, valuable for single mothers who often feel judged by the wider society, including family and pre-existing friends. Elizabeth further contrasted the quality of her friendships with relationships with family members, referencing an individualistic middle-class background where family members are expected to be independent of each other and, unlike friends, attach conditions to any support given. In this instance, individualism is associated with family rather than friendships, challenging laments of the decline of 'traditional kinship' (Bauman, 2003). It suggests the limitations of a specifically middleclass individualised model of personal life that individualisation theories tend to rely on (Skeggs, 1997):

'It's not complicated by the agenda of sex and sexuality - it's just spending time together, having a shoulder to cry on and being there for me - they're the people I value most and ... my family are there for me too but they're not and never will be one of these really close-knit model but the 
middle class you know you go off independently and make very little demand on each other kind of thing ... so it's conditional support rather than the sort of unconditional support I would get from my friends.'

\section{Acceptance}

Participants often turned to friends for acceptance and a sense of identity and belonging (May, 2013), reflecting the insight that friendships tend to flourish 'when lives are lived at odds with social norms' (Weeks et al, 2001: 51). This entailed reorientating towards those friends who understood and sympathised with their changed circumstances. For Helen, friends in similar positions had a greater understanding about her casual relationships than married friends. She thereby sought acceptance and validation for what might otherwise be construed in gendered terms as 'unrespectable' (Skeggs, 1997) ways of conducting her intimate life. Conversely, she was concerned that married friends might not feel comfortable meeting short-term partners and was careful about introducing people because of how she might be perceived - she was therefore aware of the potential for 'normalising judgement' (Foucault, 1977) from those in normative intimate situations. Some participants reported being excluded from previous couple-based friendships. One reason given for this was an implicit stereotyping of single mothers as sexual predators and a threat to other women (Simpson, 2006). Jess (39), a mother of two, described how she was no longer invited out by heterosexual couples, while maintaining friendships with lesbian couples. She thereby experienced exclusion, a failure to meet the standards of 'normalisation' (Foucault, 1977) within heterosexual hierarchies (van Every, 1996), where those in couples are positioned as superior to 'singles':

'Even in immediate social circles there is a concern with other women that you're threatening which I find enormously insulting, I really do ... one thing I hate even in my circle is the only people couples - who invite me out are the lesbian couples and the only time I got invited out by my 
hetero-couple friends was when I was in a relationship.... I don't think they are doing it on purpose, they just discount you.'

This extract suggests perceptions of single mothers as 'needy' and in desperate need of a partner, echoed in many accounts. Teresa (49), a mother of one, found that difficult financial circumstances were a further source of judgement and potential barrier to developing intimacies with men who, she perceived, might assume she primarily desired financial support. Single mothers run the risk of being judged for not subscribing to normative gendered roles, whereby a woman is provided for by a man. These scenarios reveal the cultural problematic of mothers who are also sexual beings and risk losing their sexual 'respectability' (Skeggs, 1997) by presenting as sexually available. Skeggs (1997) identifies sexual and feminine respectability as being of central significance to the identities of working-class women; in this study it also emerged as important to middle-class women, reflecting the precarity of their identities.

\section{Practical support}

New friendships were most often formed with other parents and single mothers, those who were likely to understand participants' situations (Klett-Davies, 1997). It was not simply a question of freely choosing kinship groups (Beck-Gernsheim, 1998), although there may have been elements of pragmatically and creatively reweaving support networks in response to changed circumstances (Duncan, 2011; Room, 2011). Friendship groups were formed through necessity and contained practical elements which, given the everyday challenges participants faced, should not be underestimated. Support from other mothers was often essential in managing caring responsibilities (Millar and Ridge, 2009; Canton, 2016). Jess illuminated these practical dimensions of friendship, explicating how exchanges of childcare helped her to organise her life: 
'It's my "have children round to tea day" when I can cash favours or I've got a friend who works hifts in $x$, any $x$ day she knows I can have [her child] and she will help me on her day off - other mums help enormously and actually it's easier when you take another child home with you....'

Reciprocal informal childcare arrangements such as this were frequently referred to, enabling time for domestic and paid work (Millar and Ridge, 2009). 'Domestic friendships', as identified by Cronin (2015), pragmatically centre round children and can form a core aspect of mothers' domestic lives. Such 'relationships of care' also help to facilitate employment for lone mothers (Millar and Ridge, 2009). This practical facet of friendship links to Canton's (2016) work in emphasising the importance of social networks for lone mothers who are experiencing economic hardship. This necessity reflects high childcare costs in the UK (Butler and Rutter, 2016) and the financial impacts of austerity on lone-parent families` who already tend to be financially disadvantaged and struggling to meet basic living $\operatorname{costs}^{8}$ - many will not otherwise have access to childcare. In this study financial support from friends tended to be indirect; one participant mentioned being unable to afford her prescribed antidepressants and asked her circle of friends (mainly other single mothers) to lend her some pills to tide her over (the point of her story being the discovery of how many of her single-mother friends took anti-depressants). Two described how friends had provided accommodation in their homes when they faced temporary homelessness. Informal childcare arrangements also helped to facilitate further intimacies; Karen (46), a mother of five, explained that she would not have been able to start dating if her friend had not been able to babysit and provide emotional support. Insights into these everyday lives speak to notions of interdependence (Fineman, 2004), reciprocity, relationality and embededdness (Smart, 2007; May, 2013) in contrast with individualistic, freely choosing, autonomous subjectivities implicit in detraditionalisation theories. They also bolster findings about how support networks help single mothers cope with adversity (Klett-Davies, 2007).

Yet it is important not to romanticise such friendships. As Heaphy and Davies (2012) found in their work on 'critical friendships', while friendships are often idealised or viewed in unproblematic terms, 
they can engender disappointment and ambivalence, and that was in evidence here. Jess attempted to go on holiday with a group of single mothers, but found that disparities between the women's routines created tensions, demonstrating that while single mothers can be an important source of support for each other, it is important not to overstate this or to assume they are a homogeneous group. Others distanced themselves from single mothers from different class backgrounds, at times invoking negative stereotypes, following Gillies' (2007) work on motherhood and class. One participant, for example, described younger mothers living on her council estate as having children irresponsibly and "giving the rest of us a bad name". Another alluded to an acquaintance who conformed to stereotypes of living 'on the social' with a number of children by different fathers - it was emphasised that this was not someone in her close friendship circle. In turn, such classed and racialised exclusions had an impact on the experiences of others, as will be touched on in the next section. Participants' 'personal communities' (Spencer and Pahl, 2006) were shaped through their local contexts, the wider cultural milieu and the ways in which they were perceived and in turn perceived others.

\section{Barriers to friendship}

Some participants had limited opportunities and resources to make friends, leading to social isolation. These participants felt they were not part of their local communities, due to a lack of opportunity to meet other parents, perceptions of difference around class, race, age, culture or parenting, and in some cases, discrimination due to single motherhood status and other forms of discrimination such as racism. These participants often narrated their experiences in terms of lives being spoiled, expressing unhappiness, disappointment and sometimes anger at a situation that was not of their choosing. In some cases, participants' lifestyles became incompatible with friends' after becoming a parent or single mother. Sam (33), a mother of one, described how her previous set of friends were unable to identify with her situation, being in a 'different world' where they prioritised 
social activities. This experience is likely to be common to many new parents, but is particularly pertinent for young mothers who may have children before the rest of their peer group and who find it difficult to meet others in a similar predicament. Sam subsequently became isolated in her local community on a council estate where, while there were high levels of other single-parent families, being mixed race, she was ostracised due to racism. Sophia (37), a mother of two, experienced exclusion on her council estate as a Muslim woman with a different approach to childrearing than her neighbours. Single mothers' acceptance into friendship and parenting circles was therefore contingent on their whether they 'fitted in' or 'belonged' within their locale (May, 2013), and a wider range of discriminations and exclusions, including classism and racism, are likely to have come into play.

Juliet (45), a mother of one, contrasted two areas where she had lived - one urban, multicultural environment where there were liberal attitudes towards single-parent families and where it was normal to socialise with parents from diverse backgrounds. Now, living in a suburban area where two-parent families were the norm, she described how she did not 'fit in' and was judged for her situation. She conveyed difficulty in finding friends outside the area local to her daughter's school due to financial and time constraints. Although Juliet had made one friend, she was not able to see her regularly. She explained that she would value friendships with other parents with whom to share family-orientated activities, conveying a sense of longing, which further emphasises her loneliness: 'What would be very nice would be if I could find a friend who maybe had a child and who I got on with ... you know, at weekends it would be nice to find people to hang out with, you know, go for a walk together, each lunch together, you know....'

It should be stressed that those who felt their lives had been spoiled were isolated and it may have been difficult to construct positive narratives without being able to draw on the positive framing friendship can afford (Budgeon, 2008). Furthermore, these participants were also lacking in people (coaxers) to tell their stories to (Plummer, 1995) and therefore develop their narratives and, it can 
be argued, rework their identities. Goodson's (2013) work underlines the need for people to tell, rehearse and develop their narratives. This also echoes Squire's (2008) finding that those most lacking in resources found it difficult to narrate their experiences.

\section{Beyond heteronormativity?}

Close friendships, especially those formed with other single mothers, were highly valued and given prominence within the narratives, as discussed. However, of pertinence here is the extent to which these friendships could be seen to replace romantic couple-centred family life. Certainly, participants attested to the closeness and durability of friendships formed or strengthened following the transition to lone motherhood. Susan (55), a mother of one, had made a conscious decision to remain single as she found it had given her the opportunity to enjoy female friendships and to focus on her career, creative pursuits and wellbeing, and was not convinced that a partner would necessarily enrich her life further. Susan's narrative was transformative, focusing on how her intimate needs were met mainly through friends, thereby reclaiming singleness as a positive identity, chiming with Budgeon (2008) and Simpson (2016). Contrastingly, Steph (37), a mother of one, emphasised the enduring nature of her friendships but found that friends saw each other less frequently when they re-partnered:

'One thing that I do remember after the break-up was forming this circle of female friends and they were some of the best times that I've had because we were all in similar situations and it was just so wonderful to talk to other women and it was so funny and so sad - all of these emotions - and we really built strong friendships and we still see them now you know ... people meet partners and you don't sort of hang out as much ... but we still meet up and have very strong friendships and that's something I'll take with me forever.'

Having found conventional co-habiting marriage constraining, Steph narrated how 
her current situation of living apart from her partner (Duncan and Phillips, 2010) was preferable, enabling her to retain independence and parental autonomy. In these circumstances, friends were an enduring source of intimacy, although her relationship with her romantic partner was still the central priority. Friendship, as forming a primary source of emotional closeness and support, was positioned as transient, subsiding into a lesser role once romantic partnerships began. Many participants' narratives conveyed a sense of longing for a romantic partner despite the other intimacies they enjoyed. Therefore, while friendship is positioned as a significant, durable relationship over the life course, it does not necessarily displace the romantic couple relationship ideal that continues to take 'centre stage' and is still perceived as foundational to family life (Evans, 2003; Budgeon, 2008).

\section{Conclusions}

The narrative method adopted here enabled a nuanced understanding of shifting, dynamic personal landscapes of intimacy and intimate identities that often changed dramatically following relationship breakdown. This article has identified the role of friendships in coming to the fore during such life transitions, providing acceptance and validation for those adjusting to new and widely stigmatised identities alongside changed material circumstances and, in some cases, a loosening of previous ties. To a degree, becoming a single mother expanded possibilities and opportunities for intimacies beyond the couple. Moving away from couple relationships - sometimes experienced as insular and limiting - offered an expansion of 'personal communities', a movement from 'given' (ascribed) ties towards 'chosen' ties based on shared experiences (Spencer and Pahl, 2006). Friendship was foregrounded in narratives of intimate lives that had not followed anticipated trajectories of meeting a romantic partner, getting married or cohabiting in a permanent, committed relationship and raising children within this partnership. This bolsters previous findings which posit that drawing on friendships in narrating intimate lives offers a socially acceptable identity for those in 
non-normative intimate situations (Budgeon, 2008), especially pertinent in the case of single mothers at risk of being linked to stigmatising representations. For these participants, friendships could be grounded in the 'respectably' feminine identity of motherhood (Skeggs, 1997). Friendships, especially those between single mothers, were narrated as providing reciprocal practical and emotional support alongside acceptance. Where prior ties lacked understanding or were judgemental, there was some reorientation towards friends who were more accepting. Developing supportive friendships with other single mothers could be viewed as an example of pragmatic 'improvised developments' (Duncan, 2011) in terms of intimacy. These findings also confirm findings from previous studies that have captured the importance of support networks in enabling single parents to cope with adversity and challenges in everyday life (Klett-Davies, 1997, 2007; Millar and Ridge, 2009; Canton, 2016).

There were limitations to this research - the study set out to capture a broad spectrum of intimacies as narrated by single mothers, and so this means there is limited data on specific aspects such as friendship. With a relatively small sample, it is not possible to make broad generalisations, particularly as single mothers are such a diverse group. Nevertheless, it offers some insights into the ways in which single mothers conceived of friendship, made sense of and reworked their intimate lives - enabling a re-consideration of theories of intimacy. Where friendships were established, they were depicted as meaningful and enduring, revealing 'hidden solidarities' (Spencer and Pahl, 2006), reciprocity and belonging (May, 2013), thus challenging dystopian visions of a world marked by superficial, fleeting intimacies (Bauman, 2003). Neither do they fit neatly with individualisation theories' emphasis on the freely choosing individual, given the part circumstances, constraints and necessity play in shaping intimate lives. Rather than transcending 'communities of need' (BeckGernsheim, 1998), friendships tended to be formed around proximity and necessity. It should also be noted that they were sometimes premised on exclusions regarding the 'wrong type of single mother', usually young, working-class women who most closely fitted negative stereotypes propagated in the British media (Tyler, 2008). Friendships were multifaceted, offering emotional 
disclosure, shared childcare arrangements, fun, acceptance and belonging, transcending simplistic typologies. The significance of friendships may, to an extent, reflect broader transitions, opening up possibilities beyond the heteronormative couple-based intimacies (Roseneil, 2004). Participants pragmatically adapted to their changing circumstances (Duncan, 2011), although the majority maintained an attachment to normative intimate forms, the romantic couple relationship retaining its status as an ideal (Gabb, 2010). Nevertheless, there were instances where remaining single was reframed in the narratives as a choice, preferable to being in unfulfilling, unequal, poor-quality relationships (chiming with Budgeon, 2008). Simpson (2016) similarly noted 'an emerging cultural acceptability of remaining single as an alternative, rather than a necessarily deviant, partnership status' (2016: 394). Friendship was narrated as providing emotional nourishment, support and pleasures that may be absent in couple relationships, and there were cases where fulfilling friendships, at least temporarily, superseded the need for a partner.

\section{Acknowledgements}

I would first like to acknowledge the friendship and support of my colleague Dr Tamsin Hinton-Smith who understands the experience of being a single mother working in academia, alongside all the inspiration and intellectual, practical and emotional support from friends with experience of single motherhood such as Emily Humphreys, Sarah Elliott and Natasha Steel, who make it possible to keep going. Thanks are due to my supervisory team at the University of Sussex, Dr Ben Fincham and Professor Susie Scott, who offered comments on an early draft of this article. Finally, I would like to thank the editorial team and anonymous reviewers for all their helpful suggestions and guidance.

\section{Notes}

1 It should be noted that the British Coalition government of 2010 reinstated the Married Tax Allowance. 
2 Please note that this sample was not diverse in terms of race - most participants identified as White British, with one originally from the US and one from another European country and one who identified as mixed race.

3 These narratives correspond with Klett-Davies' (2007) typology of single mothers as 'strugglers', 'copers' and 'pioneers', although a narrative focus demonstrates how participants moved through different positions over time.

4 This reflects that 90 per cent of single parents are women, according to the ONS (2017).

5 Single-parent households have been the hardest-hit household types by tax and benefit reforms since 2010: see De Agostini et al (2014).

6 Children in single-parent families are twice at risk of living in relative poverty than those in couple families (poverty rates are $47 \%$ and $24 \%$ respectively); see DWP (2017).

7 Single parent households have been the hardest hit household types by tax and benefit reforms since 2010: De Agostini, P., et al (2014) Were we really all in it together? The distributional effects of the UK coalition government's tax-benefit policy changes. London: Centre for the Analysis of Social Exclusion, London School of Economics

8 Children in single parent families are twice at risk of living in relative poverty than those in couple families (poverty rates are $47 \%$ and $24 \%$ respectively) DWP (2017) Households below average income, 1994/95 - 2015/16. Table 4.

$14 \%$ of single parent households were in fuel poverty in 2011 , twice the risk faced by couples with children. Department of Energy \& Climate Change (2013) Fuel poverty report: annual report on statistics. 2013, London, UK. 


\section{References}

Allan, G, 1989, Friendship: Developing a sociological perspective, Hemel Hempstead: Harvester Wheatsheaf

Allan, G, 2011, Introduction to friendship and emotions, Special section, Sociological Research

Online, 16, 1, www.socresonline.org.uk/16/1/15.html

Bauman, Z, 2003, Liquid love, Cambridge: Polity Press

Beck, U, Beck-Gernsheim, E, 1995, The normal chaos of love, Cambridge: Polity Press

Becker, G, 1997, Disrupted lives: How people create meaning in a chaotic world, Berkeley, CA:

University of California Press

Beck-Gernsheim, E, 1998, From a community of need to elective affinities, Theory, Culture and Society, $15,3,53-70$

Budgeon, S, 2008, Couple culture and the production of singleness, Sexualities, 11, 301-21

Butler, A, Rutter, J, 2016, Creating an anti-poverty childcare system, York: Joseph Rowntree Foundation, https://www.familyandchildcaretrust.org/creating-anti-poverty-childcare-system Butler, J, 2000, Promiscuous obedience, in S Salih, ed, The Judith Butler reader, Oxford: Blackwell Press

Canton, J, 2016, Coping with hard times: The role that support networks play for lone mother families in times of economic crisis and government austerity, Families, Relationships \& Societies, 7, $1,23-38$

Cronin, A, 2015, 'Domestic friends': Women's friendships, motherhood and inclusive intimacy, The Sociological Review, 63, 662-79 
De Agostini, P., Hills, J. and Sutherland, H. (2014) Were we really all in it together? The distributional effects of the UK Coalition Government's Tax-benefit policy changes, Working Paper no.10. London: Centre for the analysis of social exclusion, London School of Economics.

Duncan, S, 2011, Personal life, pragmatism and bricolage, Sociological Research Online, 16, 4, www.socresonline.org.uk/16/4/13.html

Duncan, S, Phillips, M, 2010, People who live apart together (LATs) - How different are they?, The Sociological Review, 58, 1, 112-34

DWP (Department for Work and Pensions), 2017, Households below average income, 1994/952015/16, Table 4

Evans, M, 1993, Reading lives: How the personal might be social, Sociology, 27, 1, 5-13

Evans, M, 2003, Love: An unromantic discussion, Cambridge: Polity PressFineman, MA, 2004, The autonomy myth: A theory of dependency, New York: The New Press

Foucault, M, 1977, A Sheridan, translator, Discipline and punish: The birth of the prison, London: Penguin [reprinted 1999]

Gabb, J, 2010, Researching intimacy in families, Basingstoke: Palgrave Macmillan

Giddens, A, 1992, The transformation of intimacy, Cambridge: Polity Press

Gillies, V, 2007, Marginalised mothers: Exploring working-class experiences of parenting, London: Routledge

Gingerbread (no date) Analysis of Labour Force Survey (April-June 2015), www.gingerbread.org.uk/content/365/Statistics

Goodson, I, 2013, Developing narrative theory: Life histories and personal representation, London and New York: Routledge 
Goodson, I, Sikes, P, 2001, Life history research in educational settings: Learning from lives, Buckingham: Open University Press

Hockey, JL, Meah, A, Robinson, V, 2010, Mundane heterosexualities: From theory to practices, Basingstoke: Palgrave Macmillan

Jackson, S, 2005, Sexuality, heterosexuality and gender hierarchy: Getting our priorities straight, in C Ingraham, ed, Thinking straight: New work in critical heterosexuality studies, New York: Routledge Jamieson, L, 1998, Intimacy: Personal relationships in modern societies, Cambridge: Polity Press Jamieson, L, Simpson, R, 2013, Living alone: Globalization, identity and belonging, Basingstoke: Palgrave Macmillan Jamieson, L, Morgan, D, Crow, G, Allan, G, 2006, Friends, neighbours and distant partners: Extending or decentering family relationships?, Sociological Research Online, 11, 3, www.socresonline.org.uk/11/3/jamieson.html Kaufman, J, 2008, The single woman and the fairytale prince, Cambridge: Polity Press Layne, L, 2015, A changing landscape of intimacy: The case of a single mother by choice, Sociological Research Online, 20, 4, 7, www.socresonline.org.uk/20/4/7.html

Klett-Davies, M, 1997, Single mothers in Germany: Supported mothers who work, in S Duncan, R Edwards, eds, Single mothers in International contexts: Mothers or workers?, London: Routledge Klett-Davies, M, 2007, Going it alone? Lone motherhood in late modernity, Aldershot: Ashgate Lieblich, A, Tuval-Maschiach, R, Zilbet, T, 1998, Narrative research: Reading, analysis and interpretation, London: Sage

May, V, 2004, Meanings of lone motherhood within a broader family context, The Sociological Review, 52, 3, 390-403 
May, V, 2013, Connecting self to society: Belonging in a changing world, London: Palgrave Macmillan McAdams, D, Bowman, PJ, 2001, Narrating life's turning points: Redemption and contamination, in D McAdams, R Josselson, Lieblich, A, eds, Turns in the road: Narrative studies of lives in transition, Washington, DC and London: American Psychological Association

Millar, J, Ridge, T, 2009, Relationships of care: Working lone mothers, their children and employment sustainability, The Journal of Social Policy, 38, 1, 103-21

Morris, C, 2014, Unsettled scripts: Intimacy narratives of heterosexual single mothers, Doctoral thesis, http://sro.sussex.ac.uk/48918

Morris, C, 2015, Considerations of equality in the intimacy narratives of heterosexual single mothers, Sociological Research Online Special Issue on Intimacy and Equality, 20, 4, 6, www.socresonline.org.uk/20/4/6.html ONS (Office for National Statistics), 2017, Families and households, 2017, Table 1

Pahl, R, Spencer, L, 2004, Personal communities: Not simply families of 'fate' or 'choice', Current Sociology, 52, 2, 199-221

Plummer, K, 1995, Telling sexual stories: Power, change, and social worlds, New York: Routledge Plummer, K, 2003 Intimate citizenship: Private decisions and public dialogues, Seattle, WA and London: University of Washington Press

Rebughini, P, 2011, Friendship dynamics between emotions and trials, Sociological Research Online, 16, 1, www.socresonline.org.uk/16/1/3.html

Riessman, CK, 1993, Narrative analysis, Newbury Park, CA: Sage

Room, G, 2011, Complexity, institutions and public policy: Agile decision-making in a turbulent world, Cheltenham: Edward Elgar Publishing 
Roseneil, S, 2004, Why we should care about friends? An argument for queering the care imaginary in social policy, in A Deacon, F Williams, eds, Social policy and society, Cambridge: Cambridge University Press

Roseneil, S, 2005, Living and loving beyond the boundaries of the heteronorm: Personal relationships in the 21st century, in S Cunningham-Burley, L McKie, eds, Families in society: Boundaries and relationships, Bristol: Policy Press

Roseneil, S, Budgeon, S, 2004, Cultures of intimacy and care beyond the family: Personal life and social change in the early twenty-first century, Current Sociology, 52, 2, 135-59

Simpson, R, 2006, The intimate relationships of contemporary spinsters, Sociological Research Online, 11, 3, http://socresonline.org.uk/11/3/simpson.html

Simpson, R, 2016, Singleness and self-identity: The significance of partnership status in the narratives of never-married women, Journal of Social and Personal Relationships, 33, 3, 385-400

Skeggs, B, 1997, Formations of class and gender: Becoming respectable, London: Sage [reprinted 2002]

Skeggs, B, 2004, Class, self, culture, London: Routledge

Smart, C, 2007, Personal life: New directions in sociological thinking, Cambridge: Polity Press

Smart, C, Neale, B, 1999, Family fragments, Cambridge: Polity Press

Spencer, L, Pahl, R, 2006, Rethinking friendship: Hidden solidarities today, Princeton, NJ and Oxford: Princeton University Press

Squire, C, 2008, Experience-centred and culturally-oriented approaches to narrative in M, Andrews, C, Squire, M, Tamboukou eds, 2008, Doing narrative research, London: Sage

Tyler, I, 2008, Chav mum, chav scum, Feminist Media Studies Online, 8, 1, 17-24 
van Every, J, 1996, Heterosexuality and domestic life, in D Richardson, ed, Theorising heterosexuality, Buckingham: Open University Press

Weston, K, 1997, Families we choose: Lesbians, gays, kinship, New York: Columbia University Press

Weeks, J, Donovan, C, Heaphy, B, 2001, Same sex intimacies: Families of choice and other life experiments, Routledge: London 